\title{
Progress in the Protection of Hawks and Owls
}

In the matter of the protection of hawks and owls one of the most progressive provinces in Canada is the province of Alberta. In Alberta the Golden Eagle is the only predator not legally protected. Recent representations from groups in Alberta desiring to have this law repealed in order to re-open legal shooting of hawks and owls have fortunately been unsuccessful. During discussions of the issue, the existing government legislation has been strongly supported by the Edmonton Bird Club which presented an able brief prepared by its Predator Committee (cf. Blue Jay, Vol. XIV, No. 1). It is interesting to know that the two major farm organizations in the province, the Alberta Federation of Agriculture and the Farmers' Union of Alberta, were also emphatic defenders of the law.

Now, naturalists in Ontario are fighting for similar protection for birds of prey. A copy of a brief submitted by the Audubon Society of Canada to the Fish and Game Committee of the Ontario Legislature, March 12, 1956, has been sent to the Editor of the Blue Jay by John Livingston, executive director of the Audubon Society of Canada. The brief outlines the history of the campaign for the protection of predators, and gives the main arguments justifying protection.

Ever since 1932 Ontario naturalists have tried to get legislation protecting hawks and owls. Eagles and the Osprey are the only predators now protected. Although no Canadian province has yet adopted the ideal legislation that exists for example in the states of Connecticut, Michigan, and Indiana, there are three that are notably advanced: Nova Scotia, Manitoba and Alberta. In Nova Scotia, all hawks and owls are protected except the Goshawk, Sharp-shinned Hawk, and Great Horned Owl. In Manitoba, all hawks and owls are protected except the Goshawk, Sharp-shinned Hawk, and Snowy Owl. In Alberta, as we have already seen, only the Golden Eagle is not protected. Ontario is felt by naturalists to be far behind these forward-looking provinces.

In its brief, the Audubon Society expressed the conviction that the arguments for protection, though familiar, bear repeating. Certain hawks and owls, for example the rodent-destroying buteos, have of course long been considered beneficial-especially since Taverner in his Birds of Canada established their "economic status" by his convincing series of stomach analyses. Blanket protection of birds of prey is necessary to guard even these obviously invaluable mousers ag a inst the shooter who mistakes them for socalled "chicken hawks." In addition however, we must consider other hawks and owls which have until recently been regarded in an unfavourable light. Today's ecological findings show that it is difficult to classify any living creature as "harmful." Certainly, under natural conditions, such hawks as the Goshawk, Cooper's and Sharp-shin do take birds. So does the Great Horned Owl. But predation is one of the controls that nature uses to maintain a healthy wildlife community. Surplusage of game birds and song birds are continually being cropped by birds of prey and other predators. Without control, any given species will increase beyond its food supply and its surplus is thus doomed to succumb to starvation and disease. Predators help to ensure that this situation does not come about. Further, by cropping the weaker individuals, predators help to guarantee a healthy and vigorous breeding population.

These arguments are valid in natural or wild conditions. Everyone is ready to accept their limitation in one artificial situation of major significance, namely, the farm. Depredations upon poultry by birds of prey must be stopped, if necessary by shooting. With this one reservation in mind, the Audubon Society has framed the following recommendation which it hopes will be received sympathetically by the Ontario Legislature: 
In Ontario every hawk and owl should be protected except that the owner of poultry or other domestic animals and the members of his immediate household and his bone fide employee may destroy by shooting any hawk or owl which is doing real damage to the said poultry or other domestic animals.

\title{
Regina Natural History Society: List of Winter Birds (1955-56)
}

\author{
By'E. L. FOX, Chairman, Bird Group,
}

Species listed are those observed November 1 to February 29 in the Regina area by F. Bard, M. Belcher, F. Brazier, E. Cruickshank, E. Fox, S. Jordan, F. Lahrman, G. Ledingham, M. Ledingham, L. Murray, and R. Nero.

During the winter the open water at the Powerhouse supported a number of waterfowl. Supplementary feeding was carried on by the Powerhouse staff with the Regina Fish and Game League supplying food. Species present: Pied-billed Grebe 2; White Pelican (one on the lake for a week early in November - E. Fox); Whistling Swans 2; Canada Geese 24 (three killed and one injured by intruders late in the winter); Mallard 200 est.; Pintail 3; Green-winged Teal 2; Lesser Scaup 5; American Goldeneye 5; American Merganser 1 (F. Lahrman); Coot 1.

A feeding station in the Legislative Building Grounds proved productive. Black-capped Chickadees, Hudsonian Chickadees and Red-breasted Nuthatch could be observed feeding or in the area on most occasions. A Brown Creeper, a Slate-coloured Junco, and a White-throated Sparrow stayed until well into December. A Northern Shrike, probably attracted by the small birds, was also present. On one occasion the Shrike was observed carrying a freshly killed Red-breasted Nuthatch in its feet ( $F$. Brazier). In the same area there were Pigeon Hawk 2; Hairy and Downy Woodpeckers; Golden-crowned Kinglets until late December); Pine Grosbeaks; Evening Grosbeaks 1 (F. Brazier); Purple Finch 2 (F. Brazier); Hoary Redpolls; Common Redpolls; Red Crossbills; White-winged Crossbills.

It is interesting to note the influx of winter birds into the Regina area this year, and to compare this list with that of 1954-1955 (Blue Jay, Vol. XIII, No. 2). Pine Grosbeaks, Red and White-winged Crossbills have been observed on most field trips and in greater numbers than for the past few years. The Hudsonian Chickadee observed occasionally most years has been resident this winter. Hoary Reppolls, recorded on a number of occasions in the city, have been observed in large flocks along roads leading out of the city. This frosty little bird which had been considered quite rare in this area was a very interesting addition to our winter list.

(Editor's Note: Stuart Houston and Frank Roy have both reported Hoary Redpolls near Saskatoon this winter, and we have a record from Wm. Anaka who identified a Hoary twice this winter at Spirit Lake. See also the Christmas Bird Count 1955. Apparently the Hsary Redpoll is more prevalent this year throughout the province.)

Interesting too is the fact that the Short-eared Owl reported frequently last year was not recorded. The Snowy Owl, was rare, indicating an approach to the low point of its cycle of migration. No doubt the very severe winter and deep snow were factors in a more southernly migration of many species.

The following additional species were reported. from other areas of the city: Sharp-tailed Grouse (group of 8 in the Provincial Nursery); Hungarian Partridge; Ring-billed Gull (one in November by F. Brazier); Snowy Owl 1; Saw-whet Owl (one by S. Jordan); Magpie; Robin (3 in November); Bohemian Waxwings (frequently throughout the city); Cedar Waxwing (one with a flock of 16 Bohemians observed on several occasions in November); English Sparrow; Rusty Blackbird Pink-sided Junco (November); Snow Bunting. Total: 42 species (21 winter birds; 10 waterfowl on open water; 11 stragglers). 